\title{
Poisoning from the Kambô ritual
}

\author{
Alexander Kumachev, MD*; Jonathan S. Zipursky, MD*; Adina S. Weinerman, MD**; Margaret \\ Thompson, $\mathrm{MD}^{\dagger \S}$
}

Keywords: toxicology, poisoning, gastrointestinal, clinical pharmacology

\section{INTRODUCTION}

The Kambô ceremony is a purification ritual that first began in South America. Poison extracted from the Amazonian giant leaf frog (Phyllomedusa bicolor) is applied transdermally to areas of the skin (often the right shoulder or the ankle) that are burned with a heated stick or vine. ${ }^{1}$ The poison induces brief, yet intense vomiting, is thought to purify the body, increase physical strength and sexual stamina, and provide a spiritual cleansing. ${ }^{1,2}$ The practice is occurring in Europe and North America, where participants have expanded traditional uses for the poison to the treatment of depression and substance abuse. The Kambô poison contains multiple active peptides: phyllocaerulein, a vasoactive peptide that promotes digestive secretions, vasoactive peptides such as phyllokinin and phyllomedusin, and the opioid-like peptides dermorphin and deltorphin., ${ }^{2,3}$ A description of the treatment of a case of Kambô poisoning, with management targeted to the effects of the endogenous peptides in the poison, has not been described in the literature.

\section{CASE}

A 32-year-old female presented to the emergency room with persistent nausea, vomiting, and abdominal discomfort at 8 hours after a Kambô ritual. The ceremony involved a shaman burning three spots on the proximal right arm and one spot on the right heel with a heated wooden stick, followed by spreading dried Kambô

poison into the wounds. Within 10 minutes, she felt nauseated and began to purge, and during the first hour she reported abdominal, chest, hand, and foot cramps. At the time of presentation to the hospital, she reported having more than 50 episodes of non-bilious emesis without hematemesis.

During a physical exam, her temperature was $37.1^{\circ} \mathrm{C}$, blood pressure was 92/55, pulse was 60 beats per minute, and oxygen saturation was $96 \%$ breathing room air. Her physical examination revealed three round burns approximately $0.5 \mathrm{~cm}$ in diameter on her right arm and one on her right ankle. The remainder of her physical examination was unremarkable. Her laboratory investigations revealed a white blood cell count of 12 (normal range: $4.0-11.0 \times 10^{9} / \mathrm{L}$ ), potassium of 3.2 $(3.5-5 \mathrm{mmol} / \mathrm{L})$, magnesium of $0.65 \quad(0.70-$ $1.05 \mathrm{mmol} / \mathrm{L})$, phosphate of $0.47(0.87-1.52 \mathrm{mmol} / \mathrm{L})$; the remainder of her serum investigations were normal, including a calcium level of $2.51 \mathrm{mmol} / \mathrm{L}$. The urine toxicology screen was positive for cannabinoids, and the patient reported to be an occasional user without previous similar symptoms. The electrocardiogram showed sinus bradycardia at a rate of 58 beats per minute.

The initial management in the emergency department was symptomatic treatment with intravenous (IV) fluids as well as ondansetron and ketorolac for the persistent nausea and abdominal pain. The on-call toxicologist at the local poison centre was consulted for further advice. Because the Kambô poison contains several powerful emetics as well as potent endogenous opioids, the patient was treated with further IV ondansetron and given a trial of IV naloxone $(0.4 \mathrm{mg})$. One hour later she was asymptomatic and discharged home.

From the *Department of Medicine, University of Toronto, Toronto, ON; †Division of Clinical Pharmacology and Toxicology, University of Toronto, Toronto, ON; ¥Division of General Internal Medicine, Sunnybrook Health Sciences Centre, Toronto, ON; and §Department of Emergency Medicine, St. Michael's Hospital, Toronto, ON.

Correspondence to: Alexander Kumachev, Department of Medicine, PGY2 Internal Medicine, University of Toronto, Toronto, ON M4N 3M5, Canada; Email: alex.kumachev@mail.utoronto.ca

(C) Canadian Association of Emergency Physicians 


\begin{tabular}{|c|c|}
\hline Peptide & Proposed mechanism of action \\
\hline $\begin{array}{l}\text { Deltorphin/ } \\
\text { dermorphin }\end{array}$ & $\begin{array}{l}\text { Heptapeptide opioid agonists with activity at the } \mu \text { - and } \delta \text {-opioid receptors. Some reports suggest that the potency is } 30 \text { - } \\
40 \text { times that of morphine. }\end{array}$ \\
\hline Phyllocaerulein & $\begin{array}{l}\text { Stimulation of smooth muscle contraction and secretion of digestive enzymes. Similar in structure and action to } \\
\text { cholecystokinin. }\end{array}$ \\
\hline Phyllokinin & Arterial smooth muscle relaxation and smooth muscle contraction. \\
\hline Phyllomedusin & Excitatory tachykinin, which excites neurons, contracts smooth muscle, and is a potent vasodilator. \\
\hline Adenoralin & Enhances the binding of adenosine agonists, causes reduction in locomotor activity. \\
\hline
\end{tabular}

\section{DISCUSSION}

The growing popularity of alternative health practices makes the understanding of their potential adverse effects important for healthcare providers. Substances used in some of these practices are unregulated and therefore adverse effects may not be known.

The Kambô ritual is a body purification ritual with a high potential for adverse reactions. After dermal application of the dried Kambô poison, participants report rapid symptom onset (within 10 minutes), and most report symptom resolution spontaneously within an hour. Several of the active peptides thought to be responsible for most of the characteristic symptoms, including nausea, vomiting, diaphoresis, facial flushing, abdominal discomfort, and urge for defecation, are listed in Table $1 .^{2,3}$

Individuals may present to the hospital with concerning electrolyte abnormalities, particularly hyponatremia. ${ }^{3}$ Some participants are instructed to fast prior to the ceremony, whereas others ingest large quantities of water as part of the purification process, which may all contribute to a decreased serum sodium level. Furthermore, one case report of hyponatremia after a Kambô ritual describes a suspected syndrome of inappropriate diuretic hormone secretion caused by pain, nausea, and possibly the peptide phyllomedusin contained within the toxin. ${ }^{4,5}$ The degree of hyponatremia in this case $(116 \mathrm{mmol} / \mathrm{L})$ following a Kambô ritual was severe enough to cause a seizure.

The peptides dermorphin and deltorphin act as agonists of the $\mu$ - and $\delta$-opioid receptors, respectively, which may result in symptoms of opioid toxicity. Opioid-mediated stimulation of the chemoreceptor trigger zone has been shown to induce nausea and vomiting. ${ }^{6-8}$ Other symptoms ascribed to stimulation of these two receptors include analgesia, dizziness, respiratory depression, and decreased gastrointestinal motility. ${ }^{9}$ In our case, this prompted an empiric trial of naloxone to alleviate symptoms possibly related to opioid toxicity. Within 10 minutes of receiving naloxone, the patient reported a mild improvement in her symptoms, and, within 45 minutes, she reported symptom resolution.

\section{CONCLUSION}

We propose that, in the assessment of patients with protracted vomiting, the possibility of Kambô poisoning should be considered if there is evidence of cutaneous wounds or a history of the use of alternative health practices. Other causes of protracted vomiting should be ruled out, including structural conditions such as bowel and gastric outlet obstructions, cannabinoid hyperemesis syndrome, and cyclic vomiting syndrome. In patients presenting with Kambô toxicity, we recommend an investigation of routine electrolytes, as well as calcium, magnesium and phosphate levels, and transaminases. ${ }^{10}$ There may be no beneficial role for skin decontamination because of the rapid onset of symptoms ascribed to the fast absorption of the Kambô poison. Management should include fluid resuscitation, correcting electrolyte abnormalities, and symptomatic treatment of nausea and vomiting, with consideration for opioid antagonists.

Competing interests: None declared.

\section{REFERENCES}

1. den Brave PS, Bruins E, Bronkhorst MW. Phyllomedusa bicolor skin secretion and the Kambô ritual. 7 Venom Anim Toxins Incl Trop Dis 2014;20:40. 
2. Erspamer V, Erspamer GF, Severini C, et al. Pharmacological studies of "sapo" from the frog Phyllomedusa bicolor skin: a drug used by the Peruvian Matses Indians in shamanic hunting practices. Toxicon 1993;31:1099- 111.

3. Negri L, Erspamer GF, Severini C, et al. Dermorphinrelated peptides from the skin of Phyllomedusa bicolor and their amidated analogs activate two, $\mu$ opioid receptor subtypes that modulate antinociception and catalepsy in the rat. Proc Natl Acad Sci USA 1992;89:7203-7.

4. Leban V, Kozelj G, Brvar M. The syndrome of inappropriate antidiuretic hormone secretion after giant leaf frog (Phyllomedusa bicolor) venom exposure. Toxicon 2016; 120:107-9.

5. Cantalamessa F, Massi M, Perfumi M. Possible influence of tachykinins on body fluid homeostasis in the rat. 7 Physiol (Paris) 1984;79:524-30.
6. Al-Hasani R, Bruchas MR. Molecular mechanisms of opioid receptor-dependent signaling and behavior. Anesthesiology 2011;115:1363-81.

7. Pathan H, Williams J. Basic opioid pharmacology: an update. Br 7 Pain 2012;6:11-6.

8. Porreca F, Ossipov MH. Nausea and vomiting side effects with opioid analgesics during treatment of chronic pain: mechanisms, implications, and management options. Pain Med 2009;10:654-62.

9. Shook JE, Watkins WD, Camporesi EM. Differential roles of opioid receptors in respiration, respiratory disease, and opiate-induced respiratory depression. Am Rev Respir Dis 1990;142:895-909.

10. Pogorzelska J, Lapinski TW. Toxic hepatitis caused by excretions of the Phyllomedusa bicolor frog - a case report. Clin Exp Hepatol 2017;3:33-4. 